\title{
Beyond the Berger Inquiry: Can Extractive Resource Development Help the Sustainability of Canada's Arctic Communities?
}

\author{
Chris Southcott, ${ }^{1}$ Frances Abele, ${ }^{2}$ David Natcher ${ }^{3}$ and Brenda Parlee ${ }^{4}$
}

(Received 21 March 2018; accepted in revised form 4 July 2018)

\begin{abstract}
The four decades since the Berger Inquiry have produced a large body of research demonstrating the positive and negative impacts of resource development on northern communities. However, little independent research has aimed to yield an understanding of how best to manage the impacts of resource development and to harness its benefits in ways that can promote long-term sustainable development. This question was the impetus for the Resources and Sustainable Development in the Arctic (ReSDA) research project funded by the Social Sciences and Humanities Research Council of Canada in 2011. Representing a network of researchers, community members and organizations, ReSDA researchers conducted a series of analyses that focused on what was needed to ensure that northern communities received more benefits from resource development and potential negative impacts were mitigated. Overall, the analyses highlight the serious gaps that remain in our ability to ensure that resource development projects improve the sustainability of Arctic communities. These gaps include a proper understanding of cumulative impacts, the ability of communities to adequately participate in new regulatory processes, the non-economic aspects of well-being, the effects of impact and benefit agreements and new financial benefits, and new mitigation activities.
\end{abstract}

Key words: resource development; extractive industries; Berger Inquiry; Arctic communities; industrial impacts

RÉSUMÉ. Pendant les quatre décennies qui ont suivi l'enquête Berger, de nombreuses recherches ont été effectuées pour montrer les incidences positives et négatives de la mise en valeur des ressources sur les collectivités nordiques. Cependant, peu de recherches indépendantes ont tâché de comprendre les meilleures façons de gérer les incidences de la mise en valeur des ressources et d'exploiter leurs retombées de sorte à favoriser le développement durable à long terme. Cette question a servi de fondement au projet de recherche sur les ressources et le développement durable dans l'Arctique (Resources and Sustainable Development in the Arctic, ou ReSDA) financé par le Conseil de recherche en sciences humaines du Canada en 2011. Les chercheurs du ReSDA représentaient un réseau de chercheurs, de membres de la communauté et d'organismes. Ils ont réalisé une série d'analyses axées sur les éléments nécessaires pour que les collectivités du Nord aient droit à plus d'avantages découlant de la mise en valeur des ressources et pour atténuer les incidences négatives potentielles. Dans l'ensemble, les analyses mettent en évidence les sérieux écarts à combler pour que les projets de mise en valeur des ressources améliorent la durabilité des collectivités de l'Arctique. Ces écarts comprennent la bonne compréhension des incidences cumulatives, l'aptitude des collectivités à participer adéquatement aux nouveaux processus réglementaires, les aspects non économiques du bien-être, les effets des ententes sur les retombées et les incidences, les nouvelles retombées financières de même que les nouvelles activités d'atténuation.

Mots clés : mise en valeur des ressources; industries extractives; enquête Berger; collectivités de l’Arctique; incidences industrielles

Traduit pour la revue Arctic par Nicole Giguère.

\footnotetext{
${ }^{1}$ Corresponding author: Department of Sociology, Lakehead University, Thunder Bay, P7B 5E1 Ontario, Canada; csouthco@lakeheadu.ca

${ }^{2}$ School of Public Policy \& Administration, Carleton University, 1125 Colonel By Drive, Ottawa, Ontario K1S 5B6, Canada

${ }^{3}$ College of Agriculture and Bioresources, University of Saskatchewan, Saskatoon, Saskatchewan S7N 5C9, Canada

${ }^{4}$ Agricultural Life and Environmental Sciences, Resource Economics and Environmental Sociology, University of Alberta, Edmonton, Alberta T6G 2R3, Canada

(C) The Arctic Institute of North America
} 


\section{INTRODUCTION}

Prior to the Berger Inquiry of the 1970s, few policy makers had challenged the idea that natural resource development in the Arctic would be good for northern residents (Abele, 2009). The popular opinion was that the extraction of nonrenewable natural resources would hasten development of the region and the creation of vibrant and growing communities (Rea, 1968). Indigenous communities were seen as needing outside assistance, and it was assumed they would benefit from entering into and participating in the modern industrial economy (Watkins, 1977). This vision changed during the 1970s: Indigenous communities, academics, and environmentalists who participated in the Berger Inquiry challenged this view and asserted Dene, Metis, and Inuvialuit land rights (Berger, 1977). The Inquiry's report found that Indigenous people of the region were not likely to benefit from immediate resource development and indeed were more likely to suffer the most from its negative impacts. Berger recommended a 10-year moratorium on pipeline construction to allow time for Indigenous land rights to be settled. The Inquiry's report, and its attention to the potential social impacts on Indigenous communities, set the tone for an important period of northern history that included the recognition of Indigenous rights and the settlement of land-claim and ultimately self-government agreements between numerous Indigenous groups and the Canadian government. The new institutional arrangements thus created have enabled northern Indigenous people to influence the pace of northern development and capture some benefits from non-renewable resource extraction (Saku, 2002; Coates, 2015; Huskey and Southcott, 2016). An opportunity now exists for development projects to contribute to northern development in new and unique ways.

While northern community members are still concerned about environmental impacts and the negative social problems related to boom periods, they also recognize that in many areas, few other options are available for employment and business development (Government of Nunavut, 2006). Some of those individuals and organizations who were initially opponents of resource development in the Arctic have become more accepting of extractive industry projects, but under certain conditions (Cournoyea, 2009).

A large body of research demonstrating the positive and negative impacts of resource development on northern communities has been produced in the four decades since the Berger Inquiry. Much of this work was submitted as evidence for regulatory hearings; however, little independent research aimed to yield an understanding of how best to manage the impacts of resource development and harness its benefits in ways that can promote longterm sustainable development. This question was the impetus for the Resources and Sustainable Development in the Arctic (ReSDA) research project funded by the Social Sciences and Humanities Research Council of Canada in
2011. Representing a network of researchers, community members, and organizations, ReSDA researchers conducted a series of analyses that focused on what was needed to ensure that northern communities would receive more benefits from resource development and that potential negative impacts were mitigated. This article summarizes the findings of these studies, which were completed between 2013 and 2016 and are available on the ReSDA website.

Generally, and not surprisingly, the studies found that conditions had changed substantially since the 1970s (Coates, 2014). Political and legal transformations have convinced many Northerners that their ability to control some aspects of development has increased (Rodon, 2018). Knowledge of potential social impacts has expanded and deepened greatly during this period (Rodon et al., 2014; Schweitzer et al., 2015). Comprehensive land-claim agreements and federal policy responses to evolving jurisprudence have created a system of environmental and social impact assessment that provides some levers for regional control of aspects of development (Noble et al., 2014). New fiscal tools have the potential to ensure that a larger share of wealth produced by extractive industry development stays in the region to help communities (Huskey and Southcott, 2014), and new mitigation techniques can better control the negative environmental impacts of potential projects (Keeling et al., 2014). Industry approaches have also made important changes: the wellbeing of northern communities is increasingly seen as an important objective of new projects (Parlee, 2016). Corporations seem to be increasingly concerned with social responsibility and have developed new ways of ensuring that benefits pass directly to communities (O'Faircheallaigh and Ali, 2008). The most notable of these for the North are impact and benefit agreements (Bradshaw et al., 2014). New studies have shown that subsistence economies are continuing to be resilient in the face of resource developments (Natcher et al., 2016a). Traditional knowledge is increasingly seen as an important part of assessing and monitoring impacts (Huntington, 2014).

At the same time, many research questions remain open. While the possibility exists that non-renewable resource development can, through its short-term benefits, help communities in the North become sustainable, this is by no means a certainty. As knowledge of social impacts has increased, so has our understanding of the potential for cumulative negative impacts (Rodon et al., 2014). While environmental and social impact assessment regimes are in place, many in the North have limited capacity to participate adequately in these processes and have their concerns considered (Noble et al., 2014). Corporate and to some extent governmental understandings of well-being are still dominated by wage-economic considerations (Schweitzer et al., 2015; Parlee, 2016). While some of the fiscal benefits of projects are passed on to communities, new problems arise (Huskey and Southcott, 2014), for example, increased drug and alcohol consumption and binge spending associated 
with new high-income jobs and the distribution of royalties and other revenues to individuals (Rodon et al., 2014). Little is known about the effectiveness of provisions contained in impact and benefit agreements, and the confidentiality surrounding these agreements is of concern to some living in these communities (Bradshaw et al., 2014). While we may know more about the impacts of extractive industry activity, we know little about the impact of the mitigation activities associated with these projects (Petrov et al., 2014).

\section{HISTORY OF RESOURCE DEVELOPMENT IN THE ARCTIC}

Prior to the Berger Inquiry, those outside the region understood resource development in the Arctic to be important primarily for its benefits to Canadians as a whole. Although Arctic resources were largely ignored until World War II, occasional finds, such as the Klondike gold rush of the late 19th century and the exploitation of oil at Norman Wells starting in 1921, had hinted at the economic value of the region (Coates, 1985; Zaslow, 1988). World War II brought a large-scale American presence in the Canadian North and forced the federal government to start paying attention to the region in order to ensure Canadian sovereignty. A post-war report from the Department of Mines and Resources (Government of Canada, 1947) was one of the first documents to consider the region for its economic importance to the country as a whole (Abele, 1987).

This notion was first expressed as a primary national goal in the Northern Vision developed by the Diefenbaker Conservatives for the election of 1958 (Diefenbaker, 1958). When first made public, the Northern Vision was meant to be a means of defending Canada against Soviet military threat (Isard, 2010). It saw the North as a source of future economic development for Canada and thus represented a re-envisioning of the National Policy of the late 19th century. The North would supply the staple commodities for future Canadian economic growth. In the same sense that the West supplied the wheat that resulted in the economic growth of Canada following Confederation, oil and gas and other minerals from the North would feed a new era of economic growth (Abele, 1987). Northern development was also promoted as a panacea for the social ills afflicting Indigenous peoples, who would benefit from education, training, and the structure of full-time wage employment. By the 1950s, federal policy had changed considerably regarding the centralization of Indigenous settlement (Damas, 2002). This shift coincided with the post-war expansion of the welfare state in Canada as a whole; the result was a rapid extension of the federal government in the North as social, health, and educational services were created in newly established communities (Rea, 1968).

As part of the northern extension of the federal welfare state, communities were established or expanded through social housing construction, and families were induced by various means to settle there. These measures went hand in hand with resource development. Urbanized life and increased wildlife regulation meant that traditional subsistence activities had to be supplemented by new forms of economic sustainability. Federal authorities saw the introduction of the wage economy as essential to ensure the success of new settlements (Abele, 1987). While some attention was given to agriculture, the commercialization of traditional harvesting, and arts and handicrafts, the dominant source of new economic activity was seen as coming from resource development. Programs were developed to create a readily available Indigenous labour force for new resource industries (Abele, 1987). These programs resulted in sometimes substantial Indigenous participation in mines in Rankin Inlet (McPherson, 2003; Cater and Keeling, 2013; Rodon et al., 2013), north Baffin (Hobart, 1982; Brubacher \& Associates, 2002; Bowes-Lyon et al., 2010; Lim, 2013; Tester et al., 2013) and Resolute (Green, 2013), as well as in oil and gas development in the western Arctic (Hobart, 1981).

\section{THE BERGER INQUIRY}

In the late $1960 \mathrm{~s}$, this new vision of northern resource industrialism was the dominant logic behind the idea to build a gas pipeline from the newly discovered gas fields in the western Canadian Arctic to markets in the south. The prime minister, Pierre Trudeau, described the pipeline construction as similar to the building of the Canadian Pacific Railway. In the same way that the CPR resulted in the growth of the Canadian West, the pipeline would stimulate the growth of the Canadian North (Abele, 1987). While serving the interests of the residents of the region may not have been a main goal of the project, it was generally assumed that some benefits, in the form of at least temporary wage employment, would ensure general support for the project in the region.

This assumption resulted in part from the fact that, until the late 1960s, the Indigenous people of Canada's North had a limited political voice. However, the federal government's 1969 white paper on Indian Policy changed this situation: it resulted in a political mobilization of Canada's Indigenous peoples and the founding of organizations that could give voice and action to their concerns (INAC, 1969). In the Northwest Territories, the creation of new organizations such as the Committee for Original Peoples' Entitlement, the Indian Brotherhood of the Northwest Territories, and the Metis Association of the Northwest Territories meant that when the pipeline was first proposed, the Indigenous peoples of the region, who had witnessed many negative impacts from previous resource development, were ready to oppose the project (Abele, 1987). A 1973 decision from the Supreme Court of the Northwest Territories (Dosman, 1975) and a minority government situation for the governing Liberal party helped pressure the federal government into appointing a commission of inquiry to 
investigate the terms and conditions under which a pipeline in the Mackenzie Valley should be constructed. To head the inquiry, they appointed Thomas Berger, a judge of the British Columbia Supreme Court. From 1974 to 1976. he led the inquiry to almost all communities likely to be affected by the development and heard from hundreds of residents, including large numbers of Indigenous people (Abele, 2014).

While its direct effect was stronger in the Mackenzie Valley and Delta than in the rest of the North, the Berger Inquiry is seen by many as a watershed moment in the development of the North (Zachariah, 1984; Bone, 2009; Dokis, 2015; Goudge, 2016). While the report was an environmental assessment of a pipeline, it also dealt with the social, cultural, and economic aspects of industrial development based on natural resources (Berger, 1977:148). It was the first major report to seriously challenge the idea that extractive resource development would be good for the region no matter what the conditions. It clearly stated, on the evidence analyzed by the inquiry, that a resource development project such as the proposed pipeline could have important negative impacts on northern communities. The report had a profound impact on a new generation of social scientists. From the moment that Volume One of Berger's (1977) report was published, social science research dealing with resource development in the North started to concentrate on elaborating the themes found in that report highlighting the negative impacts of resource development on northern communities. Its importance was not limited to northern Canada. It represented a major step in considering the social impacts of industrial development in general and was an important event for the developing field of social impact assessment. For the founders of the field, it was the Berger Inquiry which was "the first case where social impacts were considered in project decision making" (Burdge and Vanclay, 1996:63; see also Torgerson, 1980).

The potential impacts of the pipeline were dealt with in the first volume of the report. While general environmental impacts were discussed, some of the most notable observations dealt with the specific negative impacts of environmental changes on the traditional economy of the region's Indigenous communities. Berger did not believe, as some had suggested, that traditional subsistence activities were dying out and that Indigenous peoples of the region were "voting with their feet" to become part of industrial development (Berger, 1977:109). The testimony of community members showed that what he called the Native economy, renewable resource development, and the mixed economy continued to exist and thrive. This type of economy continued to be the foundation of these communities and their values. Without the ability of these communities to control outside industrial development in some way, industrial projects such as the pipeline would have a negative impact on this economy and as a result, be devastating to these communities. Berger was not opposed to industrial development, but he was opposed to a situation in which projects such as the pipeline make people in these communities feel they had no other choice but industrial development. A better approach would be to halt industrial development until the renewable resource sector could be placed on a more secure footing and industrial development could supplement traditional activities (Berger, 1977:115).

Berger examined the potentially beneficial economic impacts of the pipeline. While industry and government officials stated that the pipeline would have positive impacts on the region in the form of jobs, Berger discounted these benefits on the basis of evidence presented to the inquiry. He noted that "...we have always overestimated the extent to which native people are unemployed or underemployed" and "we have never fully recognized that industrial development has, in itself, contributed to social, economic and geographic dislocations among native peoples" (Berger, 1977:123). Other industrial developments in the Canadian North and in Alaska showed that few jobs went to Indigenous people, and those that did were for unskilled workers and short-lived. The few that did get jobs had to leave their home communities, and many were introduced to alcoholism and drug abuse. In addition, there was a concern that if jobs were to increase, the traditional economy would increasingly be seen as less relevant, and this view would have extremely negative impacts on communities.

The inquiry highlighted that, as far as the regional economy was concerned, very little of the money from the project would stay in the Northwest Territories. The resource rents would leave the region. The biggest source of new funds for the Government of the Northwest Territories would be from the sale of liquor since the territorial government had no other way to source revenues from the project. The territorial government would be responsible for dealing with many of the negative consequences of the project but would have few additional resources to deal with problems adequately. Certain northern businesses might benefit somewhat, but they would not be able to control the course of events. Outside contractors would often be the main source of services and goods, but once construction was completed, the northern businesses would have to deal with the post-project bust period.

Berger (1977:148) disagreed with those proponents who suggested that social impacts from the pipeline would be beneficial in that they would "reduce the unemployment, welfare dependence, crime, violence and alcoholism" that exist in these communities. Evidence presented to the inquiry showed that up until that point in history, exposure to industrial development had brought about important negative social impacts. Increased industrial development would bring about an increased destruction of existing social relations. Welfare dependence would increase as families were torn apart. Likewise, the destruction of the values and beliefs that have held communities together for thousands of years could not help but result in more crime and more violence. The pipeline would have negative impacts on the health of Native peoples through increased exposure to sexually transmitted and other diseases. 
It would bring about changes in diet that would increase a whole range of health problems in northern communities. The experiences of the Alaskan pipeline showed that alcohol and drug abuse would increase drastically, causing further destruction to Indigenous communities.

The building of the pipeline would have important impacts on women. While Berger did not discuss differential gender-based employment impacts, he noted that the existing housing crisis in the Northwest Territories could only become worse as a result of the pipeline. The sexual exploitation of women in the region would likely increase significantly. In addition to specific impacts on women, Berger expected social inequalities generally would increase with the construction of the pipeline since it was likely that "native people will be employed as unskilled workers on jobs that will not last beyond the period of construction...native people will find themselves on the bottom rungs of the ladder and most of them are likely to remain there" (Berger, 1977:158, 159). Finally, he stresses the overall negative impacts from further loss of Indigenous identity and self-respect that would occur as a result of the building of the pipeline.

These observations led Berger (1977) to conclude that no pipeline should be built in the Mackenzie Valley for a period of 10 years so that appropriate land claims could be settled. Effective land claims would ensure that Indigenous communities in the region could better control development forces and develop an economy that was based on their wishes and served their needs. Only under these conditions should resource development proceed.

\section{THE CURRENT SITUATION: RESDA RESULTS}

While the report of the Berger Inquiry and publications associated with it (Watkins, 1977) were largely considered the first widely known criticism of extractive resource development in the North, this theme has dominated social science research on the topic ever since (Angell and Parkins, 2011). Angell and Parkins (2011) suggest, however, that views started to change in the mid-1990s. The literature began to portray Indigenous peoples not as "passive victims" but rather as empowered participants (Angell and Parkins, 2011:71). In large part the change can be seen much more clearly in the changing political climate. The signing of modern land claim treaties in the years following the Berger Inquiry, combined with the processes of decolonization and self-government, resulted in a change of attitudes in many northern communities (Abele, 2009). While opinions regarding industrial resource development continue to divide communities, by the 1990s, many of the same community leaders who had worked so hard against extractive resource development in the 1970s were now seeing it in a new light. Land-claim settlements gave communities increased authority to control extractive resource projects (Saku and Bone, 2000). Instead of destroying traditional subsistence activities, northern actors increasingly saw the potential of using the wage economy associated with resource development to enhance and re-invigorate these activities (Southcott and Natcher, 2018). What emerged was a new vision of a mixed economy that viewed sustainable development of communities as dependent on a balance of traditional, wage, and transfer economies (Kruse, 1986; Elias, 1991). New powers for territorial governments and new mechanisms such as impact and benefit agreements meant that there was a greater chance of capturing the benefits from extractive resource projects. The experiences of the Inupiat on the North Slope of Alaska offered hope that resources could be used to build capacity in Arctic communities (Knapp and Morehouse, 1991).

Northern communities and others continue to be very much aware of the dangers of extractive resource development (Hall, 2013). Given limited options, however, community members note the need to examine how mining and oil and gas projects could potentially be used to improve community well-being (SERNNoCa, 2010). What is the potential for extractive resource development to contribute to the well-being and long-term sustainability of Arctic communities? This was the key question behind the development of the Resources and Sustainable Development in the Arctic (ReSDA) partnership. This project, which started in 2011, brought together a team of international researchers and representatives of northern governments, treaty organizations, educational institutions, and community organizations to find ways in which more benefits from resource development could flow to northern communities and any negative impacts could be mitigated. As an initial activity, ReSDA sponsored a series of gap analyses to look at what research had already been done and what needed to be done. These analyses were built around this question: what key information do communities need to decide whether resource development proposals will enhance sustainability, or will continue to work against it? To answer this question, researchers conducted a series of projects that focused on how to increase benefits and eliminate negative impacts of resource development going to communities and what future research was still needed to increase local benefits and eliminate negative impacts. Initial discussions between researchers and partners resulted in a list of 13 areas of research: the history of resource development in the Arctic, main social impacts, the measurement of social impacts, differing revenue regimes, socio-economic impact assessment processes, regional economic development strategies, community well-being, community-industry relations, impact and benefit agreements, subsistence activities and resource development, traditional knowledge and resource development, environmental issues and resource development, and women and resource development. Researchers later added an additional area, climate change and resource development, since the amount of academic work being done on climate change required ReSDA to investigate the relationship. 
Table 1 lists the primary theme of each analysis report, its lead researcher, the region concerned, and its main findings. Each report is available on the ReSDA website (www.resda. ca) and contains a detailed discussion of existing relevant literature. For this article our main objective is to briefly summarize the main findings. It should be pointed out that while the term gap analysis is used to describe the reports, much of the analysis in these reports goes beyond literature reviews.

\section{FINDINGS OF THE GAP ANALYSES}

Coates (2014:4) looked at the historical research on resource development in the Canadian North and noted that, despite some exceptions, "a southern and urban focus" has meant that historians have not been very helpful in helping northern communities to understand the past impacts of resource development. This situation is starting to change as more recent research, much of it by scholars that are part of the ReSDA network, begins to examine these questions. The previous literature generally points to a legacy of boom periods, which created great challenges for communities, followed by bust periods that left "the grand promise of long-term prosperity fueled by resource development in tatters" (Coates, 2014:6). While recent research has noted the desire of at least local Indigenous populations to participate in these activities, the problems associated with maintaining company towns meant that starting in the 1970s, companies increasingly turned to transient workforces from the south to supply labour needs. At the same time, however, the companies have realized the need to develop "strong collaborative relations (or impact and benefit agreements) with regional Indigenous communities, offering skills training and jobs, business preferences and other economic benefits" (Coates, 2014:8). He notes that Indigenous communities now have "opportunities presented by resource development," and historical research can help northern communities better understand what happened in the past in order to provide better policy options in the future (Coates, 2014:17).

Arctic communities considering resource development in their traditional territories need to know what has worked - and what has not worked - in other jurisdictions, with other Indigenous populations, and with various resource projects. At present, information is substantially anecdotal, without the substantial and sustained analysis that an historical investigation would produce.... (Coates, 2014:18)

One of the major improvements to have occurred since the Berger Inquiry that could enable communities to better control extractive resource development is the evolution of our understanding of social impacts. Schweitzer et al. (2015) note that in Alaska, Greenland, and Russia, the Berger Inquiry resulted in a more elaborate understanding of the social impacts of extractive industry development on communities. In all of these regions, social impacts are now better understood and openly discussed to varying degrees; however, economic impacts are often given priority. While most of the economic impacts appear to be treated as being good for communities, they note that problematic impacts are also identified. Environmental damage can have a negative impact on a local economy as can the loss of jobs when an operation shuts down.

Generally, however, Schweitzer et al. (2015) point out that non-economic impacts do not seem to be as well understood or emphasized in discussions of social impacts. In particular they indicate that a better understanding of subsistence and cultural values is needed. While the impact of resource development on subsistence activities has been studied, there appears to be a need for a better understanding of these impacts. People in these communities are very concerned that the relationship between extractive industry and traditional subsistence activities is not properly understood. Another social impact that needs more research concerns migration. Little is understood about the impacts of transient labour arriving in the region. While often these workers are isolated in work camps, interaction does occur. Our understanding of the impact of industrial employment on migration trends in northern Indigenous communities also needs improvement. When operations cease, does staying in their home communities help people, or does it help them to leave?

Similar conclusions are reached by Rodon et al. (2014) in their study of social impacts in Canada. While there has been much work in northern Canada on environmental impacts, social impacts are much less studied. Most of the research is contained in non-peer reviewed grey literature. This literature tends to note the positive economic impacts gained through employment and through increased revenues flowing to northern communities as a result of land-claim agreements and impact and benefit agreements. At the same time, rapid increases in disposable income often produce harmful "boom" effects, such as alcohol or drug abuse, gambling, and prostitution, which can lead to increased violence, exploitation of women, mental illness, suicide, and family perturbations. Other potential detrimental economic impacts are high inflation and increased dependence on extractive industries.

Less is known about the non-economic social impacts, but the existing research tends to paint a negative picture. Increased health problems due to boom effects have already been mentioned. Social cohesion often suffers, as does the ability of women to contribute to the community's well-being. Existing reports have also noted increased intergenerational and regional inequalities. In discussions of the impacts of extractive industry on traditional subsistence economies, opinion seems to be split, with some suggesting that work schedules have a negative impact while others point to wages' enhancing such activities (Rodon et al., 2014:10). 
TABLE 1. ReSDA gap analysis projects.

\begin{tabular}{|c|c|c|c|c|}
\hline Report & Gap analysis theme & Lead researcher & Region covered & Main gaps \\
\hline 1 & History of resource development in the Arctic & Ken Coates & Primarily Canada & $\begin{array}{l}\text { More northern focus, new relations with } \\
\text { Indigenous communities, what worked in the past }\end{array}$ \\
\hline $2 \mathrm{~A}$ & $\begin{array}{l}\text { Impacts of resource developments on communities } \\
\text { - Alaska, Russia, Greenland }\end{array}$ & Peter Schweitzer & $\begin{array}{l}\text { Alaska, Russia, } \\
\text { Greenland }\end{array}$ & $\begin{array}{l}\text { Non-economic social impacts, importance } \\
\text { of subsistence and cultural values, impacts of } \\
\text { new transient workforce, migration impacts }\end{array}$ \\
\hline $2 \mathrm{~B}$ & $\begin{array}{l}\text { Impacts of resource developments on communities } \\
\text { - Canadian Arctic }\end{array}$ & Thierry Rodon & Canada & $\begin{array}{l}\text { Non-economic impacts, negative "boom" } \\
\text { impacts, health and social cohesion impacts }\end{array}$ \\
\hline 3 & $\begin{array}{l}\text { Measurements of social and economic impacts of } \\
\text { resource developments }\end{array}$ & Andrey Petrov & All Arctic & $\begin{array}{l}\text { More common, better integrated and adequate } \\
\text { baseline indicators, locally relevant "qualitative" } \\
\text { indicators for contextual information, more } \\
\text { community involvement }\end{array}$ \\
\hline 4 & Resource revenue regimes & Lee Huskey & All Arctic & $\begin{array}{l}\text { Revenue flows, ways to maximize local benefits, } \\
\text { distribution challenges, saving mechanisms }\end{array}$ \\
\hline 5 & $\begin{array}{l}\text { Social, economic, and environmental impact } \\
\text { assessments }\end{array}$ & Bram Noble & All Arctic & $\begin{array}{l}\text { Relevance of regulatory process and engagement } \\
\text { of northern communities, cumulative and } \\
\text { regional impacts }\end{array}$ \\
\hline 6 & Regional development & Frances Abele & All Arctic & $\begin{array}{l}\text { Impacts of colonialism, locally based innovations, } \\
\text { community engagement to develop policy }\end{array}$ \\
\hline 7 & Resource development and well-being & Brenda Parlee & Primarily Canada & $\begin{array}{l}\text { Community-based notions of well-being, } \\
\text { importance of education and culture for well-being }\end{array}$ \\
\hline 9 & Impact and benefit agreements & Ben Bradshaw & Primarily Canada & $\begin{array}{l}\text { Relationships between IBAs and regulatory } \\
\text { processes, processes by which IBAs are negotiated } \\
\text { and implemented, IBAs and "the pursuit of social } \\
\text { justice" }\end{array}$ \\
\hline 10 & Indigenous subsistence economies & David Natcher & Primarily Canada & $\begin{array}{l}\text { How to ensure recognition of subsistence activities } \\
\text { as a normal part of local economy, effectiveness of } \\
\text { support mechanisms }\end{array}$ \\
\hline 11 & $\begin{array}{l}\text { Traditional knowledge and resource development } \\
\text { in the Arctic }\end{array}$ & Henry Huntington & All Arctic & $\begin{array}{l}\text { Influence of traditional knowledge on decision } \\
\text { making, experiences of traditional knowledge } \\
\text { holders, infrastructure to support traditional } \\
\text { knowledge }\end{array}$ \\
\hline 12 & Resources and environmental issues & Arn Keeling & Primarily Canada & $\begin{array}{l}\text { Involvement of local communities in mitigation and } \\
\text { remediation activities }\end{array}$ \\
\hline 13 & Resource development and climate change & Chris Southcott & All Arctic & Infrastructure impacts, potential long-term impacts \\
\hline 14 & Gender and northern resource development & Suzanne Mills & Primarily Canada & $\begin{array}{l}\text { Gendered effects of socio-economic development, } \\
\text { gender impact mitigation attempts, gender impacts } \\
\text { of financial benefits and procurement }\end{array}$ \\
\hline
\end{tabular}

The relative lack of knowledge about social impacts points to an important issue facing extractive industry development in the North: how (and whether) these impacts can be measured. Any attempt to reduce the damaging impacts and increase the benefits of extractive resource development depends largely on an adequate system to measure socio-economic change in northern communities. In their analysis dealing with the socio-economic measurement of resource activity impacts, Petrov et al. (2014) note that improvements have been made over the past 40 years. At the same time, problems still exist. Their report reviews socio-economic impact assessment measurement across the circumpolar North. While there is a great deal of variation between jurisdictions, there are common challenges. These include fragmentary measuring systems; a lack of integration of indicators used in assessment, monitoring, and management; inadequate baseline data; and a limited ability to understand broader impacts of industrial activity. They also note that current systems tend to have a "quantitative tilt" and lack qualitative data, which can provide more locally relevant and contextual information. In general, northern communities need to be better included in the measurement process and less dependent on "imported variables" and experts (Petrov et al., 2014:8).
The review and measurement of social impacts have become a formal part of the regulatory process for extractive industry in the North through environmental assessment. The increasing use of this environmental management tool across the circumpolar North since the 1970s represents a substantial improvement in the potential control and mitigation of negative impacts on northern communities. Yet, as Noble et al. (2014) point out in their analysis, in recent years the effectiveness of environmental assessment (EA) has been increasingly questioned. After surveying recent EA research across the Arctic, they note that the EA process has been criticized as increasingly cumbersome to industry. At the same time, very little is known about how northern communities feel about the processes. Research on whether communities feel the current regulatory system is meeting their expectations and needs has been extremely limited. This is especially true for Indigenous communities.

Concerns also exist regarding other questions, such as whether the EA process is actually influencing decision making or whether current project-based systems allow for an adequate consideration of cumulative and regional impacts. Another question is whether current processes allow for the meaningful engagement of northern communities. Recently questions have arisen about 
whether these communities have the capacity to adequately participate in EA (Noble et al., 2014). More research has to be done to find out whether community voices are being heard and if not, what can be done to improve the situation.

Since the 1960s, staples theory has been used to explain that extractive resource development is a poor option for the development of a region since it provides few economic linkages. Most of the profits, or rents, leak out of the region, leaving it in a "staples trap" (Watkins, 1963:151). New modern comprehensive land claims, decolonization, and new self-government initiatives mean that northern communities in many areas of the Arctic now have the ability to reduce these leakages by capturing a higher percentage of these resource rents. In their survey of existing resource revenue regimes across the Arctic, Huskey and Southcott (2014) note increasing evidence of new fiscal linkages occurring in at least some parts of the region. A larger percentage of royalties and taxation are staying in the North, and new vehicles (such as impact and benefit agreements and partnership arrangements) are helping to reduce leakages, but we are not sure to what extent. More research needs to be done on where this new money goes and which regimes give the maximum fiscal linkages. Are northern communities actually benefiting from increased extractive industry revenues? Recent research on the issue of the "resource curse" notes increased problems that develop when extractive industry revenue flows into a region (Humphreys et al., 2007). Research and innovation are needed to find the best ways for communities and regions to both distribute and save these revenues.

Federal attempts to redress uneven development across Canada have waxed and waned since the $1950 \mathrm{~s}$ (Savoie, 1992). The North has often been included as a region of focus for these policies. Resource development has been prioritized as an area that can assist in regional development in the circumpolar North. As Abele (2016) points out in her analysis of regional development in the Arctic, only in Fenno-Scandia has evidence been found that extractive resource development provides self-sustaining growth. For this to happen, we need to turn to more locally based, "ground up" innovations, something difficult to do given the colonial past of northern communities. Extractive industry development is likely to contribute to the long-term sustainability of northern regions only if we can develop new regionally designed and relevant policy instruments that are the result of community engagement. These instruments must balance the enduring four pillars of northern economies: harvesting, public investment, mineral development, and the wage sector based on heterogeneous renewable resources (Abele, 2016).

Any attempt to evaluate benefits and mitigate negative impacts of resource development requires an idea of what sort of development communities are aspiring to. Common indicators of development based on economic success are not adequate for most communities in Canada's North. Parlee (2016) points out that the notion of well-being is a more appropriate basic concept to use in evaluating indicators of positive or negative impacts. In her analysis, she discusses how the notion of well-being allows us to better understand important potential benefits. While well-being includes the notion of material benefits, such as employment and financial capital, the Indigenous communities of northern Canada tend to highlight other social aspects as being important to their notion of wellbeing. In these communities, education, culture, and their relationship to the land are some aspects that take a more central place in the definition of well-being and therefore need to be given a central place in any evaluation of benefits and costs of resource development. More research is needed for us to properly understand the various definitions of well-being that exist in each community.

As mentioned above, impact and benefit agreements, or IBAs, have been one of the most readily identifiable new ways that northern communities can ensure greater benefits from resource development. In their gap analysis report, Bradshaw et al. (2014) note that the use of IBAs in northern Canada over the past 20 years has not been problem-free. They review scholarship focused on IBAs to highlight what is known and identify gaps in our knowledge. Three dominant areas of research on IBAs are identified: the relationships between IBAs and the existing regulatory processes, the processes by which IBAs are negotiated and implemented and their relative effectiveness, and finally the relationship between IBAs and "the pursuit of social justice" (Bradshaw et al., 2014:3). The literature notes that the relationship between IBAs and existing regulatory processes is problematic, and more work needs to be done to ensure that IBAs support existing processes rather than conflicting with them. We also need to better understand how effective IBAs are at ensuring an increase in community well-being. Problems still exist in terms of the ability of communities to negotiate adequate agreements and then ensure that the terms of these agreements are adequately implemented. Finally, a bigger question that must be answered is whether IBAs are "redressing historical injustices or perpetuating further injustice" (Bradshaw et al., 2014:11). We need more research to ensure that these agreements truly support decolonization and are not simply "neocolonization."

A major concern of the Berger Inquiry was the potentially devastating impact of industrial development on the traditional subsistence economy of northern Indigenous communities. Since the 1970s, a number of new institutions have been negotiated to provide northern residents with some control over the forces of economic development. Comprehensive land-claim agreements, self-government arrangements, and new co-managed regulatory systems increase the ability of northern communities to control those aspects of development that would have damaging impacts on the subsistence economy. What is currently happening to these types of activities? Existing studies of whether traditional subsistence economies are being helped or hindered by resource development show contradictory findings. In their research, Natcher et al. $(2012,2016 a)$ found 
that one of the biggest obstacles to resource development potentially supporting subsistence activities is that existing policies still hold the biased opinion that the wage-based economy is the only legitimate economic activity for these communities. Rather than being treated as an informal or remedial form of economic production, subsistence harvesting requires the same level of support that is given to industrial wage-earning opportunities (Natcher et al., 2016b). In some areas (e.g., Nunavut, Nunavik), various hunter support programs have provided this support, but in others (e.g., Yukon, Labrador), subsistence harvesters are left to their own devices with no institutional support mechanisms made available.

Another important aspect of well-being in northern communities is the protection and valuation of traditional knowledge; therefore, it is important to understand the relationship between this form of understanding and resource development. Huntington (2014) surveys the inclusion of traditional knowledge in resource development decision making. He notes that, largely because of the political demands of Indigenous peoples, traditional knowledge is increasingly being used in various decisions about resource development. This practice has already been shown to have benefited communities by giving them more of a voice in these decisions. At the same time, we have little knowledge of the extent to which the increased legitimacy given to traditional knowledge is actually influencing decisions and reshaping the way resource development is done in the North. We need to know more about how traditional knowledge holders view their experiences in decision making for resource development, what type of infrastructure best supports the effective use of traditional knowledge, and how much the use of traditional knowledge depends upon power relations in a given context.

While the objective of the ReSDA research was to concentrate on the socio-economic and cultural aspects of resource development, the environment occupies such an important aspect of life in the North that it must be included in any discussion of benefits and detrimental impacts. While other gap analyses dealt with environmental considerations as part of their discussions, Keeling et al. (2014) addressed the issue of environmental impacts in terms of what these mean for northern communities. Since the Berger Inquiry, new regulatory measures linked to impact assessments now require industry proponents to address potential impacts, which has increased their ability to understand and mitigate the negative environmental effects of resource development. At the same time, less research has been devoted to studying the ability of northern communities to become involved in these assessment and mitigation activities. Keeling et al. (2014) echo a concern expressed in other gap analyses: that while co-management of the environment has been accepted in principle, the extent to which northern Indigenous communities can integrate their traditional knowledge into discussions of environmental impacts is less evident, especially as concerns nonrenewable resource development. They find that little work has been done on the degree to which northern communities benefit from, or are negatively affected by, the management of the "environmental legacies" of extractive industry projects.

Substantial research has been done on the present and future impacts of climate change in the Arctic (Duerden, 2004; Nickles et al., 2005; Berkes and Armitage, 2010; Pearce et al., 2010; Ford et al., 2012). There is much speculation that climate change is causing an increase in resource development in the region-indeed, "opening" the Arctic in unprecedented ways (Borgerson, 2008). Southcott (2014) reviewed the existing literature on climate change, concentrating on research dealing with resource development. Existing data show little evidence that climate change is resulting in increased Arctic resource development (Ford et al., 2008, 2010; Pearce et al., 2011; Southcott, 2014). Existing models do project future conditions that may improve the circumstances under which resource development in the Arctic can occur, but they also indicate other conditions that may negatively affect these developments (ACIA, 2005; Furgal and Prowse, 2008). While there is little evidence of a direct relationship between climate change and current Arctic resource development, shorter periods for use of winter roads and deteriorating infrastructure are likely to be detrimental to these activities in the immediate future. Over the longer term, melting sea ice may eventually allow for easier shipping access to project sites in the Arctic but here again the unpredictability of sea ice as a result of climate change is likely to become a problem in the medium term.

Research that examines gender differences relating to resource development has a long history. Much of this research points out that in the past, women have received few benefits from these activities and have been subjected to a range of detrimental impacts. Mills et al. (2014), who analyzed the current situation in the Arctic, show that women in northern communities receive fewer economic benefits than men in terms of direct industry employment; however, since these women often have higher levels of education than men, they benefit from indirect employment opportunities related to social services, administration, or business ventures. There is research that indicates a high level of concern among women relating to the boom effects of resource development in a community (Mills et al., 2014). The increase in money as a result of new employment opportunities and royalty payments tends to produce a range of social issues such as increased alcohol and drug abuse, sexual exploitation, and family violence. Finally, these authors note that women are concerned about the negative impacts of resource development on subsistence activities. They add that improved understanding of the gendered effects of socio-economic development in northern communities is needed to help us learn how to ensure that gender differences do not represent a barrier to communities that seek to improve their well-being through resource development. 
Much of the needed work discussed above has already begun. Recent historical research on resource development in the region has resulted in a much better understanding of its impacts on northern communities (Keeling and Sandlos, 2015; Sandlos and Keeling, 2016b; Huskey, 2018). Other work on social impacts has contributed to a better understanding of non-economic impacts and different impacts within communities (Jones and Bradshaw, 2015; Parlee, 2015; Stienstra et al., 2017), including the issues surrounding cumulative impacts (Atlin and Gibson, 2017; Kirkfeldt et al., 2017). A number of researchers have added to our understanding of barriers to adequate community participation in both the environmental assessment processes and the negotiations of impact and benefit agreements (Cox and Mills, 2015; Dokis, 2015; Noble and Udofia, 2015; Udofia et al., 2015; McCreary et al., 2016). Several publications have enhanced our understanding of the relationship between subsistence activities and resource development (Natcher et al., 2016b; Parlee et al., 2018; Southcott and Natcher, 2018). A number of recent works have furthered our understanding of the nature and impacts of resource rents and how to conserve them for northern communities (Aragon, 2015; Kadenic, 2015; Huskey and Southcott, 2016; Thistle, 2016; O'Faircheallaigh, 2018). Finally, recent research has looked at the impacts of workforce mobility (Jones and Southcott, 2015; Saxinger and Gartler, 2017), governance issues (Ritsema et al., 2015; Rodon, 2018), and problems facing remediation processes (Dance, 2015; Sandlos and Keeling, 2016a).

\section{CONCLUSIONS}

Overall, the analyses reviewed above confirm that serious gaps in knowledge remain, which limit our ability to ensure resource development projects contribute to the sustainability of Arctic communities. Despite more recent research, we still do not have an adequate understanding of how the social and environmental legacies of past resource developments continue to affect northern communities. Our knowledge of social impacts has increased, but it is still inadequate for understanding those social impacts that fall outside the traditional economic indicators. Attempts are being made to develop adequate systems for measuring and monitoring such impacts, but much work remains to be done, especially as concerns the involvement of these communities in the collection and control of this information. While environmental assessment regimes are in place across the region, we still do not know if these processes are meeting the needs of northern communities and whether these communities are being heard. New revenue regimes are offering the promise of increased financial linkages flowing to northern communities, but we have little information on the extent to which this is true or the impact these new revenues are having on these communities. Research on regional economic policy indicates that most recent attempts to use extractive resource development to help ensure sustainable development have failed in the Arctic and that we still have not been able to develop adequate regionally relevant policy instruments to assist in this regard. The process of developing more adequate notions of wellbeing to guide development decisions has only just begun. We still do not adequately understand whether impact and benefit agreements are actually helping to increase community well-being. While the traditional subsistence economy remains strong in some areas of the Arctic, our inability to consider subsistence activities as a normal part of development in the North means that the impacts of industrial resource development on these activities are unclear. Traditional knowledge is increasingly being included in resource development, but we do not know the extent to which it is actually influencing decisions. Knowledge about environmental impact mitigation and remediation has increased substantially since the Berger Inquiry, but we have little knowledge of the involvement of local communities in these processes. Finally, while some negative gender impacts have lessened recently, we still do not have a good understanding of gender differences relating to resource developments.

On the positive side, the ReSDA gap analyses found that the way resource development is considered in the Arctic has changed considerably since the 1970s. Increasing attention is being paid to ensuring that northern communities benefit from any new projects. New modern comprehensive land-claim agreements in Canada, movements towards self-government, and changing attitudes have meant that northern communities have more control over these projects than they ever had previously. In addition to these changes, our knowledge of potential social impacts has increased substantially. A conversation has started about finding the best ways to measure, monitor, and mitigate these impacts. We now have environmental impact assessment regimes in place that try to determine what social impacts would result from proposed projects and ensure that these impacts are monitored and, to the extent possible, mitigated. New revenue regimes in most regions of the Arctic are meant to ensure that communities and regions receive a fair share of financial benefits from resource development. The need for and implementation of impact and benefit agreements is now almost universally accepted in much of the Arctic. Our notions of development are increasingly open to more holistic notions of well-being that are more in line with the aspirations of northern communities. We are increasingly aware of how important traditional subsistence economies are for these communities and the need to consider these activities a "normal" part of development. Environmental concerns are now central to discussions of whether resource development projects should proceed. We are also increasingly aware of the differing gender impacts of resource development in the region. 


\section{REFERENCES}

Abele, F. 1987. Canadian contradictions: Forty years of northern political development. Arctic 40(4):310-320. https://doi.org/10.14430/arctic1788

- 2009. Northern development: Past, present and future. In: Abele, F., Courchene, T.J., Seidle, F.L., and St-Hilaire, F., eds. Northern exposure: Peoples, powers and prospects in Canada's North. Montreal, Quebec: Institute for Research on Public Policy. 19-65.

- 2014. The immediate and lasting impact of the inquiry into the construction of a Mackenzie Valley pipeline. In: Inwood, G.J., and Johns, C.M., eds. Commissions of Inquiry and Policy Change: A comparative analysis. Toronto, Ontario: University of Toronto Press. 88-110.

. 2016. Regional development in the circumpolar North: What else do we need to know? Gap Analysis Report \#6. Whitehorse, Yukon: ReSDA. 13 p.

http://yukonresearch.yukoncollege.yk.ca/resda/wp-content/ uploads/sites/2/2013/09/Gap-Analysis-6-final-2017.pdf

ACIA (Arctic Climate Impact Assessment). 2005. Arctic climate impact assessment: Scientific report. Cambridge: Cambridge University Press.

Angell, A.C., and Parkins, J.R. 2011. Resource development and Aboriginal culture in the Canadian North. Polar Record 47(1):67-79. https://doi.org/10.1017/S0032247410000124

Aragon, F.M. 2015. Do better property rights improve local income?: Evidence from First Nations' treaties. Journal of Development Economics 116:43-56. https://doi.org/10.1016/j.jdeveco.2015.03.004

Atlin, C., and Gibson, R. 2017. Lasting regional gains from nonrenewable resource extraction: The role of sustainabilitybased cumulative effects assessment and regional planning for mining development in Canada. The Extractive Industries and Society 4(1):36-52. https://doi.org/10.1016/j.exis.2017.01.005

Berger, T.R. 1977. Northern frontier, northern homeland: The report of the Mackenzie Valley Pipeline Inquiry. 3 vols. Ottawa: Mackenzie Valley Pipeline Inquiry.

Berkes, F., and Armitage, D. 2010. Co-management institutions, knowledge, and learning: Adapting to change in the Arctic. Études/Inuit/Studies 34(1):109-131. https://doi.org/10.7202/045407ar

Bone, R.M. 2009. The Canadian North: Issues and challenges. Don Mills, Ontario: Oxford University Press.

Borgerson, S.G. 2008. Arctic meltdown: The economic and security implications of global warming. Foreign Affairs 87:63-77.

Bowes-Lyon, L.-M., Richards, J.P., and McGee, T.M. 2010. Socio-economic impacts of the Nanisivik and Polaris mines, Nunavut, Canada. In: Richards, J.P., ed. Mining, society, and a sustainable world. Berlin: Springer-Verlag. 371-396.
Bradshaw, B., Fidler, C., and Wright, A. 2014. Impact and benefit agreements \& northern resource governance: What we know and what we still need to figure out. Gap Analysis Report \#9. Whitehorse, Yukon: ReSDA.

http://yukonresearch.yukoncollege.yk.ca/resda/projects/gapanalysis/gap-9/

Burdge, R.J., and Vanclay, F. 1996. Social impact assessment: A contribution to the State of the Art Series. Impact Assessment 14(1):59-86. https://doi.org/10.1080/07349165.1996.9725886

Brubacher \& Associates. 2002. The Nanisivik legacy in Arctic Bay: A socio-economic impact study. Prepared for the Department of Sustainable Development, Government of Nunavut. Ottawa, Ontario: Brubacher \& Associates.

Cater, T., and Keeling, A. 2013. "That's where our future came from": Mining, landscape, and memory in Rankin Inlet, Nunavut. Études/Inuit/Studies 37(2):59-82. https://doi.org/10.7202/1025710ar

Coates, K. 1985. Canada's colonies: A history of the Yukon and Northwest Territories. Toronto, Ontario: James Lorimer \& Company.

- 2014. The history and historiography of natural resource development in the Arctic: The state of the literature. Gap Analysis Report \#1. Whitehorse, Yukon: ReSDA. 19 p. http://yukonresearch.yukoncollege.yk.ca/resda/projects/gapanalysis/gap-1/

- 2015. Sharing the wealth: How resource revenue agreements can honour treaties, improve communities, and facilitate Canadian development. Ottawa, Ontario: MacdonaldLaurier Institute.

Cournoyea, N.J. 2009. Navigating and managing economic, environmental and social change in the Inuvialuit Settlement Region. In: Abele, F., Courchene, T.J., Seidle, F.L., and StHilaire, F., eds. Northern exposure: Peoples, powers and prospects in Canada's North. Montreal, Quebec: Institute for Research on Public Policy. 389-393.

Cox, D., and Mills, S. 2015. Gendering environmental assessment: Women's participation and employment outcomes at Voisey's Bay. Arctic 68(2):246-260. https://doi.org/10.14430/arctic4478

Damas, D. 2002. Arctic migrants/Arctic villagers: The transformation of Inuit settlement in the central Arctic. Montreal, Quebec: McGill-Queen's University Press.

Dance, A. 2015. Northern reclamation in Canada: Contemporary policy and practice for new and legacy mines. Northern Review 41:41-80. https://doi.org/10.22584/nr41.2015.003

Diefenbaker, J.G. 1958. A new vision: Notes for a speech given at the Civic Auditorium, Winnipeg, Manitoba, 12 February 1958. http://www.canadahistory.com/sections/documents/ Primeministers/diefenbaker/docs-thenorthernvision.htm

Dokis, C.A. 2015. Where the rivers meet: Pipelines, participatory resource management, and Aboriginal-State relations in the Northwest Territories. Vancouver, British Columbia: UBC Press. 
Dosman, E.J. 1975. The national interest: The politics of northern development 1968-75. Toronto, Ontario: McClelland and Stewart.

Duerden, F. 2004. Translating climate change impacts at the community level. Arctic 57(2):204-212.

https://doi.org/10.14430/arctic496

Elias, P.D. 1991. Development of Aboriginal People's communities. North York, Ontario: Captus Press.

Ford, J., Pearce, T., Prno, J., Duerden, F., and Marshall, D. 2008. Global Warming - Climate change impacts on the Canadian mining sector. Canadian Mining Journal, April 6, 2008.

http://www.canadianminingjournal.com/news/globalwarming-climate-change-impacts-on-the-canadian-miningsector/

Ford, J.D., Pearce, T., Prno, J., Duerden, F., Ford, L.B., Beaumier, M., and Smith, T. 2010. Perceptions of climate change risks in primary resource use industries: A survey of the Canadian mining sector. Regional Environmental Change 10(1):65 -81. https://doi.org/10.1007/s10113-009-0094-8

Ford, J.D., Bolton, K.C., Shirley, J., Pearce, T., Tremblay, M., and Westlake, M. 2012. Research on the human dimensions of climate change in Nunavut, Nunavik, and Nunatsiavut: A literature review and gap analysis. Arctic 65(3):289-304. https://doi.org/10.14430/arctic4217

Furgal, C., and Prowse, T.D. 2008. Northern Canada. In: Lemmen, D.S., Warren, F.J., Lacroix, J., and Bush, E., eds. From impacts to adaption: Canada in a changing climate 2007. Ottawa, Ontario: Government of Canada. 57-118.

Goudge, S.T. 2016. The Berger Inquiry in retrospect: Its legacy. Canadian Journal of Women and the Law 28(2):393 - 407. https://doi.org/10.3138/cjwl.28.2.393

Government of Canada. 1947. Canada's new northwest. Ottawa: King's Printer.

1969. Statement of the Government of Canada on Indian Policy. Ottawa: Department of Indian and Northern Affairs, 1969.

http://epe.lac-bac.gc.ca/100/200/301/inac-ainc/indian policy-e/cp1969_e.pdf

Government of Nunavut. 2006. Parnautit: A foundation for the future-mineral exploration and mining strategy. Iqaluit: Department of Economic Development \& Transportation. https:/gov.nu.ca/sites/default/files/Parnautit_Mineral_ Exploration_and_Mining_Strategy.pdf

Green, H. 2013. State, company, and community relations at the Polaris mine (Nunavut). Études/Inuit/Studies 37(2):37-57.

Hall, R. 2013. Diamond mining in Canada's Northwest Territories: A colonial continuity. Antipode 45(2):376-393. https://doi.org/10.1111/j.1467-8330.2012.01012.x

Hobart, C.W. 1981. Performance of Native trainees in an apprenticeship training program. The Canadian Journal of Native Studies 1(1):33-58.

- 1982. Inuit employment at the Nanisivik mine on Baffin Island. Etudes/Inuit/Studies 6(1):53-74.

Humphreys, M., Sachs, J.D., and Stiglitz, J.E., eds. 2007. Escaping the resource curse. New York: Columbia University Press.
Huntington, H. 2014. Traditional knowledge and resource development. Gap Analysis Report \#11. Whitehorse, Yukon: ReSDA. 21 p.

http://yukonresearch.yukoncollege.yk.ca/resda/projects/gapanalysis/gap-11/

Huskey, L. 2018. An Arctic development strategy? The North Slope Inupiat and the resource curse. Canadian Journal of Development Studies 3(1):89-100.

https://doi.org/10.1080/02255189.2017.1391067

Huskey, L., and Southcott, C. 2014. Resource revenue regimes around the circumpolar North. Gap Analysis Report \#4. Whitehorse, Yukon: ReSDA. 32 p.

http://yukonresearch.yukoncollege.yk.ca/resda/projects/gapanalysis/gap-4/

- 2016. "That's where my money goes": Resource production and financial flows in the Yukon economy. The Polar Journal 6(1):11-29.

INAC (Indian and Northern Affairs Canada). 1969. Statement of the Government of Canada on Indian Policy, 1969. Ottawa: INAC.

http://epe.lac-bac.gc.ca/100/200/301/inac-ainc/indian_ policy-e/cp1969_e.pdf

Isard, P. 2010. Northern vision: Northern development during the Diefenbaker era. Waterloo, Ontario: University of Waterloo. http://hdl.handle.net/10012/5032

Jones, C., and Southcott, C. 2015. Mobile miners: Work, home, and hazards in the Yukon's mining industry. Northern Review 41:111- 137 .

Jones, J., and Bradshaw, B. 2015. Addressing historical impacts through impact and benefit agreements and health impact assessment: Why it matters for Indigenous well-being. Northern Review 41:81 - 109.

Kadenic, M.D. 2015. Socioeconomic value creation and the role of local participation in large-scale mining projects in the Arctic. Extractive Industries and Society 2(3):562 - 571.

https://doi.org/10.1016/j.exis.2015.04.010

Keeling, A., and Sandlos, J., eds. 2015. Mining and communities in northern Canada: History, politics, and memory. Calgary, Alberta: University of Calgary Press.

Keeling, A., Sandlos, J., Boutet, J.-S., and Longley, H. 2014. Managing development? Knowledge, sustainability and the environmental legacies of resource development in northern Canada. Gap Analysis Summary 12. Whitehorse, Yukon: ReSDA. 37 p.

http://yukonresearch.yukoncollege.yk.ca/resda/projects/gapanalysis/gap-12/

Kirkfeldt, T.S., Hansen, A.M., Olesen, P., Mortensen, L., Hristova, K., and Welsch, A. 2017. Why cumulative impacts assessments of hydrocarbon activities in the Arctic fail to meet their purpose. Regional Environmental Change 17(3):725 - 737. https://doi.org/10.1007/s10113-016-1059-3

Knapp, G., and Morehouse, T.A. 1991. Alaska's North Slope Borough revisited. Polar Record 27(163):303-312.

Kruse, J. 1986. Subsistence and the North Slope Inupiat: The effects of energy development. In: Langdon, S.J., ed. Contemporary Alaskan Native economies. Lanham, Maryland: University Press of America. 121-152. 
Lim, T.W. 2013. Inuit encounters with colonial capital: Nanisivik Canada's first High Arctic mine. Resource Management and Environmental Studies. MA thesis, University of British Columbia, Vancouver.

McCreary, T., Mills, S., and St-Amand, A. 2016. Lands and resources for jobs: How Aboriginal peoples strategically use environmental assessments to advance community employment aims. Canadian Public Policy 42(2):212-223.

McPherson, R.L. 2003. New owners in their own lands: Minerals and Inuit land claims. Calgary, Alberta: University of Calgary Press.

Mills, S., Dowsley, M., and Cameron, E. 2014. Gender in research on northern resource development. Gap Analysis Report \#14. Whitehorse, Yukon: ReSDA.

http://yukonresearch.yukoncollege.yk.ca/resda/projects/gapanalysis/gap-14/

Natcher, D.C., Felt, L., and Procter, A., eds. 2012. Settlement, subsistence and change among the Labrador Inuit: The Nunatsiavummiut experience. Winnipeg: University of Manitoba Press.

Natcher, D., Felt, L., Procter, A., and Haalboom, B. $2016 \mathrm{a}$. Normalizing Aboriginal subsistence economies in the Canadian North. Gap Analysis Report \#10 Final. Whitehorse, Yukon: ReSDA.

http://yukonresearch.yukoncollege.yk.ca/resda/wp-content/ uploads/sites/2/2013/09/Natcher-Gap-Analysis-final-for-web. pdf

Natcher, D., Shirley, S., Rodon, T., and Southcott, C. $2016 \mathrm{~b}$. Constraints to wildlife harvesting among Aboriginal communities in Alaska and Canada. Food Security 8(6): $1153-1167$.

Nickels, S., Furgal, C., Buell, M., and Moquin, H., eds. 2005. Unikkaaqatigiit: Putting the human face on climate change: Perspectives from Inuit in Canada. Joint publication of Inuit Tapiriit Kanatami, Nasivvik Centre for Inuit Health and Changing Environments at Université Laval and the Ajunnginiq Centre at the National Aboriginal Health Organization.

Noble, B., and Udofia, A. 2015. Protectors of the land: Toward an EA process that works for Aboriginal communities and developers. Ottawa, Ontario: Macdonald-Laurier Institute. https://doi.org/10.13140/RG.2.1.1988.2964

Noble, B., Hanna, K., and Gunn, J. 2014. Northern environmental assessment: A gap analysis and research agenda. Gap Analysis Report \#5. Whitehorse, Yukon: ReSDA.

http://yukonresearch.yukoncollege.yk.ca/resda/projects/gapanalysis/gap-5/

O'Faircheallaigh, C. 2018. Using revenues from Indigenous impact and benefit agreements: Building theoretical insights. Canadian Journal of Development Studies 39(1):101 - 118 .

O'Faircheallaigh, C., and Ali, S., eds. 2008. Earth matters: Indigenous peoples, the extractive industries and corporate social responsibility. Sheffield: Greenleaf Publishing Ltd.

Parlee, B.L. 2015. Avoiding the resource curse: Indigenous communities and Canada's oil sands. World Development $74: 425-436$.

https://doi.org/10.1016/j.worlddev.2015.03.004
2016. Resource development and well-being in northern Canada. Gap Analysis Report \#7. Whitehorse, Yukon: ReSDA. $15 \mathrm{p}$.

http://yukonresearch.yukoncollege.yk.ca/resda/projects/gapanalysis/gap-7/

Parlee, B.L., Sandlos, J., and Natcher, D.C. 2018. Undermining subsistence: Barren-ground caribou in a "tragedy of open access.” Science Advances 4(2): e1701611.

https://doi.org/10.1126/sciadv.1701611

Pearce, T., Smit, B., Duerden, F., Ford, J.D., Goose, A., and Kataoyak, F. 2010. Inuit vulnerability and adaptive capacity to climate change in Ulukhaktok, Northwest Territories, Canada. Polar Record 46(2):157-177. https://doi.org/10.1017/s0032247409008602

Pearce, T.D., Ford, J.D., Prno, J., Duerden, F., Pittman, J., Beaumier, M., Berrang-Ford, L., and Smit, B. 2011. Climate change and mining in Canada. Mitigation and Adaptation Strategies for Global Change 16(3):347-368.

Petrov, A., Berman, M., Graybill, J., Cavin, P., Cooney, M., Kuklina, V., and Rasmussen, R.O. 2014. Measuring impacts: A review of frameworks, methodologies and indicators for assessing socio-economic impacts of resource activity in the Arctic. Gap Analysis Report \#3. Whitehorse, Yukon: ReSDA. http://yukonresearch.yukoncollege.yk.ca/resda/projects/gapanalysis/gap-3/

Rea, K.J. 1968. The political economy of the Canadian North. Toronto, Ontario: University of Toronto Press.

Ritsema, R., Dawson, J., Jorgensen, M., and Macdougall, B. 2015. "Steering our own ship?" An assessment of self-determination and self-governance for community development in Nunavut. Northern Review 41:157-180. https://doi.org/10.22584/nr41.2015.007

Rodon, T. 2018. Institutional development and resource development: The case of Canada's Indigenous peoples. Canadian Journal of Development Studies 39(1):119-136. https://doi.org/10.1080/02255189.2017.1391069

Rodon, T., Lévesque, F., and Blais, J. 2013. De Rankin Inlet à Raglan, le développement minier et les communautés inuit. Études/Inuit/Studies 37(2):103-122.

Rodon, T., Lévesque, F., Grenier, J., and Keller, J. 2014. Gap analysis: Mining development in northern Canada. Gap Analysis Report \#2B. Whitehorse, Yukon: ReSDA.

http://yukonresearch.yukoncollege.yk.ca/resda/projects/gapanalysis/gap-2/

Saku, J.C. 2002. Modern land claim agreements and northern Canadian Aboriginal communities. World Development 30(1):141- 151 .

https://doi.org/10.1016/S0305-750X(01)00095-X

Saku, J.C., and Bone, R.M. 2000. Looking for solutions in the Canadian North: Modern treaties as a new strategy. The Canadian Geographer 44(3):259-270. https://doi.org/10.1111/j.1541-0064.2000.tb00708.x

Sandlos, J., and Keeling, A. 2016a. Aboriginal communities, traditional knowledge, and the environmental legacies of extractive development in Canada. The Extractive Industries and Society 3(2):278-287. 
2016b. Toxic legacies, slow violence, and environmental injustice at Giant Mine, Northwest Territories. Northern Review 42:7-21.

Savoie, D. 1992. Regional development: Canada's search for solutions. Toronto, Ontario: University of Toronto Press.

Saxinger, G., and Gartler, S. 2017. The mobile workers guide: Fly-in/fly-out and rotational shift work in mining. Yukon experiences. Whitehorse, Yukon: First Nation of Na-cho Nyak Dun and ReSDA.

Schweitzer, P., Stammler, F., Ebsen, C., Ivanova, A., and Litvina, I. 2016. Social impacts of non-renewable resource development on Indigenous communities in Alaska, Greenland and Russia. Gap Analysis Report \#2A. Whitehorse, Yukon: ReSDA. http://yukonresearch.yukoncollege.yk.ca/resda/projects/gapanalysis/gap-2/

SERNNoCa (The Social Economy Research Network for Northern Canada). 2010. Nunavut Summit on the Social Economy Proceedings, 25-27 November 2009, Iqaluit, Nunavut. 94 p. http://yukonresearch.yukoncollege.yk.ca/frontier/files/ sernnoca/NunavutSummitontheSocialEcon.pdf

Southcott, C. 2014. Resource development and climate change: A gap analysis. ReSDA Gap Analysis Report \#13. Whitehorse, Yukon: ReSDA.

http://yukonresearch.yukoncollege.yk.ca/resda/projects/gapanalysis/gap-13/

Southcott, C., and Natcher, D. 2018. Extractive industries and Indigenous subsistence economies: A complex and unresolved relationship. Canadian Journal of Development Studies 39(1):137-154.

https://doi.org/10.1080/02255189.2017.1400955
Stienstra, D., Manning, S.M., Levac, L., and Baikie, G. 2017. Generating prosperity, creating crisis: Impacts of resource development on diverse groups in northern communities. Community Development Journal. 18 p. https://doi.org/10.1093/cdj/bsx022

Tester, F.J., Lambert, D.E.J., and Lim, T.W. 2013. Wistful thinking: Making Inuit labour and the Nanisivik mine near Ikpiarjuk (Arctic Bay), northern Baffin Island. Études/Inuit/ Studies 37(2):15-36.

Thistle, J. 2016. Forgoing full value? Iron ore mining in Newfoundland and Labrador, 1954-2014. The Extractive Industries and Society 3(1):103-116.

Torgerson, D. 1980. Industrialization and assessment - Social impact assessment as a social phenomenon. York University Publications in Northern Studies. Toronto: York University.

Udofia, A., Noble, B., and Poelzer, G. 2015. Community engagement in environmental assessment for resource development: Benefits, emerging concerns, opportunities for improvement. Northern Review 38:98-110.

Watkins, M. 1963. A staple theory of economic growth. Canadian Journal of Economics and Political Science 29(2):141 - 158. https://doi.org/10.2307/139461

— _, ed. 1977. Dene Nation: The colony within. Toronto, Ontario: University of Toronto Press.

Zachariah, M. 1984. The Berger Commission Inquiry Report and the revitalization of Indigenous cultures. Canadian Journal of Development Studies 5(1):65-77. https://doi.org/10.1080/02255189.1984.9670080

Zaslow, M. 1988. The northward expansion of Canada 1914-1967. Toronto, Ontario: McClelland and Stewart. 